and in different ages applied successive checks to cerebral evolution, which Dr. Fauvelle regards as identical with human progress.-On the hand and figure of native East Indians, by Dr. Mugnier. In this exhaustive article the author gives elaborate measurements based on his own observations of the maxima and minima and the means of every part of the hand specially, and of the body generally, in the six principal Asiatic races, with tables of comparative measurements of Europeans. From these it is seen that the absolute size of the hand among Asiatics is less than in Europeans, the Japanese approximating most closely to the estimates given for the latter, while the Malays exhibit the lowest maximum. In regard to stature, and relative proportions of figure, all Asiatics are inferior to Europeans, the Japanese presenting the greatest divergence, while the Arabs of Y emen approximate most nearly to the general means of European races. - An anthropological and ethnographic study of the kingdom of Cambodia, by Dr, E. Maurel. Shaded maps of the territorial divisions of Indo-China frum the seventh century to the present time curionsly illustrate the varying supremacy of Siamese, Laos, and Cambodian tribes in that portion of the Far East which lies between the China Sea and the Indian Ocean. The rapidity with which alluvial deposits are formed would seem to justify the author's assertion that the territories now known as Cochin-China and South Cambodia are of recent geological origin, and were possibly submerged till near the dawn of actual historical ages. Interesting information is supplied as to the effect on the land, and the habits and pursuits of the people, of the regular inundations to which the country is exposed by the overflow of the Mekong, the great river which, rising in East Tibet, flows south ward till it divides into three branches in the heart of Cambodia, and ultimately forms the important inland sea of Toulé Sap, whose area exceeds 3000 kilometres before the return of the current temporarily diminishes its volume. The orography and the climatology of the district are carefully treated, but the materials seem still wanting for supplying us with any exact data as to the numbers and ethnic character of the population. -Platycnemia in man and the Anthropoda, by M. Manouvrier. After describing the actual anatomical characters of this peculiar lateral flattening of the tibial bone, the writer considers the grounds on which this condition has been regarded as a character of inferiority by which certain prehistoric and other ancient races would seem to show their affinity to the anthropomorpha. This opinion he absolutely rejects, and finally asserts, as the result of his comparative anatomical investigations of fossil and recent tibiæ, that platycnemia has existed and still exists among the most different human races, although it is of very rare occurrence among certain savage peoples, as the Negroes of Africa, and the Indians of California. He denies that it is a special simian characteristic, since, notwithstanding its frequent occurrence in the chimpanzee and gorilla, it does not present the same features in them as in man, and finally he believes that, even if it were originally transmitted from some arboreal anthropoid, it has been maintained simply by the activity of an essentially human function, its survival being most frequent among nations and tribes addicted to hunting and fishing, or compelled by sudden and great differences of elevation, or extreme inequalities of the surface, to make exertions in ascending and descending steep heights, by which the tibial bones are continuously and often violently exercised. Finally, platycnemia manifests itself only in the human and anthropoid adult, the young being free from it.

\section{SOCIETIES AND ACADEMIES. SYDNEY.}

Royal Society of New South Wales, May. 2. -Annual Meeting. - C. S. Wilkinson, Government Geologist, President, in the chair. - The report stated that twenty-four new members had been elected during the year, and the total number on the roll on April 30 was 482. - Dr. Michael Foster, F.R.S., Pro. fessor of Physiology, University of Cambridge, had been elected an honorary member.--During the year the Society held nine meetings, at which the following papers were read:-Presidential Addréss, by Christopher Rolleston, C. M.G.-Recent work on flying machines, by L. Hargrave.-Some N.S.W. tan-substances, Parts I, 2, 3, and 4, by J. H. Maiden.- Notes on the experience of other countries in the administration of their water supply, by H. G. McKinney.--Notes on some inclusions observed in a specimen of the Queensland opal, by D. A. Porter. - The influence of bush fires in the distribution of species, by Rev. R. Collie.-Origin and mode of occurrence of gold-bearing veins and of the associated minerals, by Jonathan Se vver.-Results of observations of comets vi. and vii., I886, at Windsor, N.S. IV., by John Tebbutt.-Port Jackson silt beds, by F. B. Gipps. - On the presence of fusel oil in beer, by W. M. Hamlet.--Autographic instruments used in the development of flying machines, by Lawrence Hargrave. - The Medical Section held seven meetings, fourteen papers being read; the Sanitary Section four meetings, five papers read; and the Microscopical Section held eight meetings. - The Clarke Medal for the year I 888 had been awarded to the Rev. J. E. Tenison-Woods; the Society's bronze medal and money prize of $£ 25$ had been awarded to $\mathrm{Mr}$. Jonathan Seaver for his paper on the origin and mode of occurrence of gold-bearing veins and of the associated minerals; and the Council has since issued the following list of subjects, with the offer of the medal ancl a prize of $f 25$, for each of the best researches, if of sufficient merit ; (to be sent in not later than May I, 1888) anatomy and life-history of the Echidna and Platypus; anatomy and life-history of Mollusca peculiar to Australia; the chemical compssition of the products from the so-called kerosene shale of New South Wales; (to be sent in not later than May $\mathbf{x}, \mathbf{I} 889$ ) on the chemistry of the Australian gums and resins; on the aborigines of Australia; on the iron ore deposits of New South Wales; list of the marine fauna of Port Jackson, with descriptive notes as to habits, distribution, \&c. ; (to be sent in not later than May I, I890) influence of the Australian climate, general and local, in the development and modification of disease; on the silver ore deposits of New South Wales; on the occurrence of precious stones in New South Wales, with a description of the deposits in which they are found.-The Chairman read the Presidential Address, and the officers and Council were elected for the ensuing year. $-A$ compressed air-engine for driving a flying machine was extibited by Mr. L. Hargrave. The engine weighed only 2 lbs. $7 \mathrm{oz}$. cylinder, $\mathrm{I} \frac{\pi}{3}$ inch diameter; stroke, 2 inches. The receiver for the compressed air was 0.21 cubic feet capacity, made of $\frac{1}{10}$-inch steel, single riveted and brazed. The bursting pressure was 900 lbs., working pressure 500 lbs., and reduced pressure 900 lbs., per square inch. There would be 9200 foot-pounds available for work; this power would have to be expended in from half to three-quarters of a minute. The charged receiver weighed 6 lbs. 12 oz., wood and paper work about 2 lbs. A small Richards's indicator hat been made for adjusting the piston-valve. The machine was intended for a flight of 200 yards.

June 6.--Sir Alfred Roberts, President, in the chair.--The Chairman announced that the Council had awarded the Society's medal and prize of $£ 25$ to the Rev. J. E. Tenison- IVoods for his paper upon the anatomy and life-history of Mollusca peculiar to Australia. - The following papers were read :-Notes on some minerals and mineral localities in the northern districts of New South Wales, by D. A. Porter.-Forest destruction in New South Wales, and its effect on the flow of water in watercourses, and on the rainfall, by W. E. Abbott.-The increasing maznitude of $\eta$ Argûs, by H. C. Russell, F.R.S. - On a simple plan of easing railway curves, by W. Shellshear.-Indi. genous Australian forage plants (exclusive of grasses), including plants injurious to stock, by J. H. Maiden.

July 4.- Sir Alfred Roberts, President, in the chair. - A discussion took place upon Mr. W. E. Abbott's paper on forest destruction in New South Wales, and its effect on the flow of water in watercourses and on the rainfall, read at the preceding meeting. The general result of the discussion was to the effect that the destruction of forests had no appreciable effect on the rainfall.--The following papers were read:-On an improvement in anemometers, by H. C. Russell, F.R.S.-On the anatomy and life-history of Mollusca peculiar to Australia, by the Rev. J. E. Tenison-Woods, in which the author gave evidence as to the existence of eyes in the skulls of many Australian Mollusca.

PARIS.

Academy of Sciences, August 27.-M. Janssen, President, in the chair.-Observations relative to a previous communication on a general property of elastic solid bodies, by M. Maurice Lévy. The author's attention has been called by M. Boussinesq to the fact that the final formula of his note inserted in the Comptes rendus of August $\mathrm{I} 3$ is found in Prof. Betti's lectures on the theory of electricity. He consequently points out that the theorem, which forms the chief object of that note, must also be accredited to the same illustrious geometrician. - Observations of 
Brooks's comet made at the Observatory of Algiers with the $0.50 \mathrm{~m}$. telescope, by MM. Trépied, Sy, and Renaux. The observations are for the period from August I I to Angust I5 inclusive. On the former date the brilliancy of the nucleus was about equal to that of a star of the tenth magnitude; diameter of nebulosity about $\mathrm{I}^{\prime}$, with faint tail in the direction of the diurnal movement.- Observations of Faye's comet made at the Observatory of Nice, by M. Perrotin. These observations were made on August II, I4, and I7.-On some experiments with the marine telephone, by M. A. Banaré. These experiments were carried out by order of the Minister of Marine, at Brest, by means of the apparatus to which the author has given the name of "hydrophone." Sounds emitted by various sonorous instruments, such as bells, whistles, and trumpets, were distinctly heard, that of a bell weighing I 50 kilogrammes at a distance of 5200 metres. The experiment, with a ship under way also gave favourable results, and here also the ringing of a bell was clearly detected at a distance of 1400 metres simultaneously with the noise of the engine and screw of the tug.- On the remains and zoological affinities of Tostudo pcrpiniana, a gigantic fossil turtle of the Perpignan Pliocene epoch, by M. P. Fischer. This magnificent specimen, discovered by M. A. Donnezan, and rescribed by M. Ch. Dépéret, has recently been acquired by the Palæontological Department of the Paris Museum. A comparative study of the remains (various parts of the carapace) leads to the conclusion that it must have been a gigantic species of a living African group (Testudo fardalis, sulcata). Iis affinities with the gigantic turtles at present confined to the Aldabra Islands in the Indian Ocean, and the Galapagos in the Pacific, do not appear to have been established. Its relations with the Chersites of South Europe are also doubtful, so that it may be considered as a Pliocene survival in the south of France of an older land fauna of an African type. Its ancestors may perhaps be found amongst the large turtles discovered by M. Gaudry in the Mount Léberon beds, but which are known only by some fragments of the carapace.-The Secretary announced the death of Herr Rudolf Clausius, Corresponding Member of the Section for Mathematics, who died at Bonn on August 24 .

\section{BERLIN.}

Physiological Society, August 3.-Prof, du Bois Reymond, President, in the chair--Dr. A. König gave an account of researches which he had carried out, in conjunction with Dr. Brodhun, for the experimental testing of Hechner's psychophysical law in its relationship to the sense of sight. In the case of lights whose brightness varied between the limits $\frac{1}{200}$ anc 200000 of the unit used, it was necessary to measure at six different points of the spectrum-that is to say, for six different kinds of monochromatic light-the minimum change of intensity which could be appreciated as a change at all. The experiments were carried out on the trichromatic eye of the speaker and the dichromatic eye of Dr. Brodhun. The observer sat in a dark chamber, into which the eye end of the observing telescope projected, and was able, by the rotation of a handle, to vary the relative $b$ rightness of the upper and lower half of the field of vision until the difference was just perceptible. The field of vision was illuminated by a double slit, through which the pure spectral red, orange, yellow, green, blue, or violet light could be admitted. The upper half of the slit was fixed, while the lower half could be widened or narrowed by the observer, and the amount of the alteration in width of the slit observed and recorded by an assistant. The source of light used was a gas-burner with zirconium light. Several thousand separate observations were made, from which it was found that the several colour-systems have no infuence on the sensitiveness to differences in brightness of lights; the values obtained in the case of Dr. König's eye were identical with those obtained for Dr. Brodhun's. The shape of the curve which expressed the percentage relationship of the least possible perceptible change in intensity (expressed as an ordinate) to the intensity of the light itself (expressed as an abscissa) was the same for all the above six colours, differing only in the case of lights of minimal intensity. The curve was not a straight line for all intensities of light which were investigated, as it should be according to Fechner's law. In the case of the greatest and least intensities of light it was found that the smallest increase of intensity which was just perceptible was greater than in the case of medium intensities of light. With weak illumination the curve for lights of greater wave-length, such as red, orange, and yellow, was sieeper than for lights of shorter wave-length. From this the speaker pointed out that the divergence in the curves of sensitiveness to varying intensities commences with that intensity at which, according to Purkinje, the subjective sensitiveness to lights of different kinds changes as their intensity is diminished, and in the same way as does the sensitiveness to varying intensities. The speaker concluded with some interesting considerations respecting the zero-point of the curve and the negative parts of the abscissæ. - Dr. Uhthoff gave an account of experiments made with a view to determining the amount of change in wave-length of spectral lights which are necessary to produce the least perceptible difference in their colour. The object of the experiments was to subject the results obtained by Drs. König and Dieterici to a renewed testing, in answer to objections which had been raised against them. Using the same apparatus, but a different method, he had confirmed their results. He also found, as Pearce had done in 1883 , that the sensitiveness to change of colours is greatest for yellow and blue, and least for red and green.

BOOKS, PAMPHLETS, and SERIALS RECEIVED.

Peginner's Guide to Photography, and edition (Perken).-A Ribliography of the Foraminifera from $x_{5} 65$ to 1888 : C. D. Sherborn (Dulati).--Hand buch der Palaentologie, i. Abtheilung, Palarzoologie, iii. Band, 2 Jiefg. (München).-1)r. H. G. Bronn's Klassen und Ordnungen des Thier. Reichs, Erster Pand. Protozoa, 47, 48, u. 49, Liefg. : Dr. O. Bütschli (Leipzig) - A T'ext-book of Euclid's Elements. Parts I and 2, containing Books i.-vi. H. S. Hall and F. H. Stevens (Macnillan). - Catalogue of the Fossil RepH. S. Hall and F. H. Stevens (Macmillan). - Catalogue of the Fossil Rep-
tilia and Amphibia in the British Museum (Natural History), Part I: R.
I.ydekker (London). - Forschungsreise S.M.S. Gaselle. iv. Theil, lotanik Algcin: Prof. I)r. E. Askenasy (Berlin).-Journal of the Chemical Society, Algcil: Prof. Dr. E. Askenasy
september (Gurney and Jack=on.

\section{CONTENTS.}

Geological Nomenclature. By Prof. John W. Judd,

F.R.S.

\section{Letters to the Editor:-}

Lamarckism versus Darwinism.-Edward B. Poul-

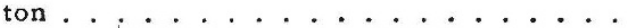

The Zodiacal Light and Meteors.-T. W. Back. house.

The Services of Catholic Missionaries in the East to Natural Science . . . . . . . . . . 434

The Australasian Association for the Advancement

of Science . . . . . . . . . . . . 437 Professor Rudolf Julius Emanuel Clausius. By G.

W. de Tunzelmann. . . . . . . . . . . 43

The British Association . . . . . . . . . . 439 Inaugural Address by Sir Frederick Bramwell, D.C.L., F.R.S., M.Inst.C.E., President . . 440 Section A.-Mathematical and Physical Science.Opening Address by Prof. G. F. Fitzgerald, M.A., F.R.S., President of the Section . . . . 446

Section C.-Geology.-Opening Address by W. Boyd Dawkins, M.A., F.R.S., F.G.S., F.S.A., Professor of Geology and Palxontology in Owens College, President of the Section ..... . 449

Notes . . . . . . . . . . . 451

Astronomical Phenomena for the Week 1888

September 9-15 . . . . . . . . . 454

Geographical Notes ......... 455

Notes on Meteorites. II. By J. Norman Lockyer, F.R.S.

Molecular Physics : an Attempt at a Comprehensive Dynamical Treatment of Physical and Chemical

Forces. II. By Prof. F. Lindemann . . . . . 458

The Forestry School in Spain . . . . . . . 465

Scientific Serials ........... 462

Societies and Academies ........ 463

Books, Pamphlets, and Serials Received .... 464 